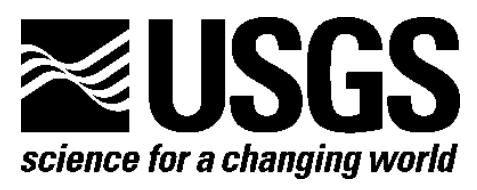

\title{
Advancing Geodesy in the U.S. Midcontinent: Workshop Report
}

By Michael W. Hamburger, Oliver S. Boyd, Eric Calais, Nancy E. King, and Seth A. Stein

Open-File Report 2014-1169

U.S. Department of the Interior

U.S. Geological Survey 


\section{U.S. Department of the Interior \\ SALLY JEWELL, Secretary}

\section{U.S. Geological Survey \\ Suzette M. Kimball, Acting Director}

U.S. Geological Survey, Reston, Virginia: 2014

For more information on the USGS-the Federal source for science about the Earth,

its natural and living resources, natural hazards, and the environment-visit

http://www.usgs.gov or call 1-888-ASK-USGS

For an overview of USGS information products, including maps, imagery, and publications, visit $h$ ttp://www.usgs.gov/pubprod

To order this and other USGS information products, visit http://store.usgs.gov

Suggested citation:

Hamburger, M.W., Boyd, O.S., Calais, Eric, King, N.E., and Stein, S.A., 2014, Advancing geodesy in the U.S. Midcontinent-Workshop report: U.S. Geological Survey Open-File Report 2014-1169, 22 p., http://dx.doi.org/10.3133/ofr20141169.

ISSN 2331-1258 (online)

Any use of trade, firm, or product names is for descriptive purposes only and does not imply endorsement by the U.S. Government.

Although this information product, for the most part, is in the public domain, it also may contain copyrighted materials as noted in the text. Permission to reproduce copyrighted items must be secured from the copyright owner. 


\section{Contents}

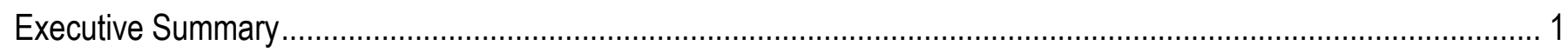

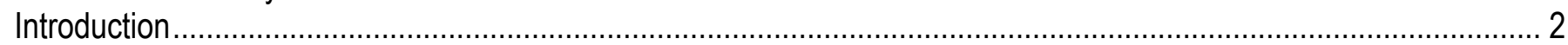

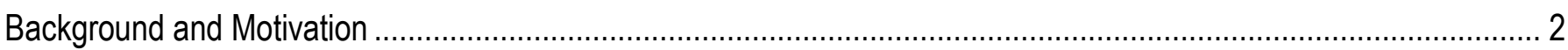

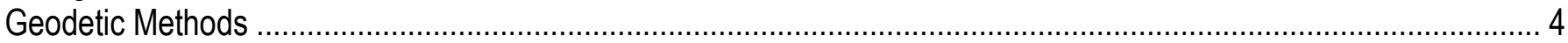

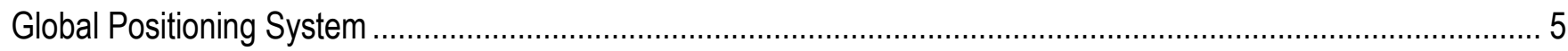

Interferometric Synthetic Aperture Radar .............................................................................................

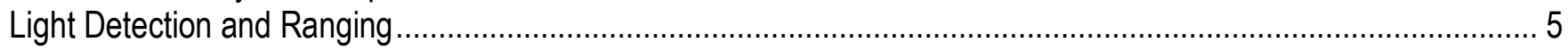

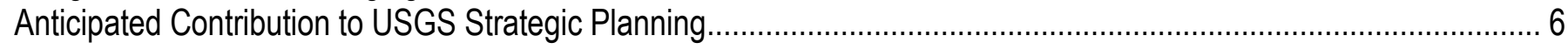

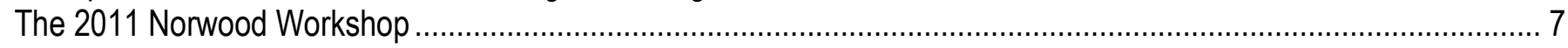

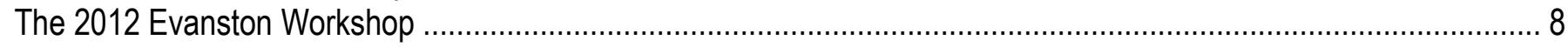

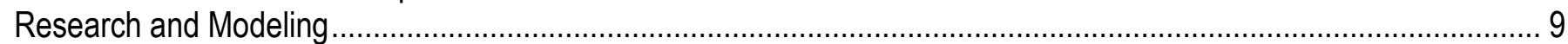

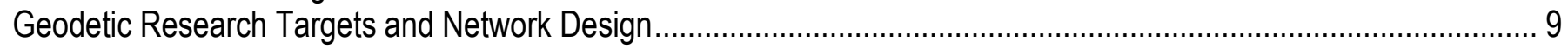

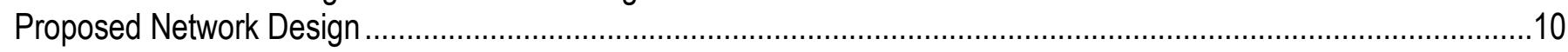

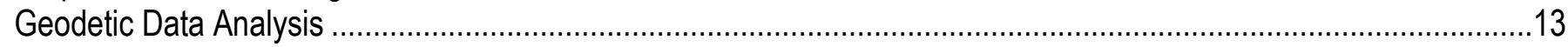

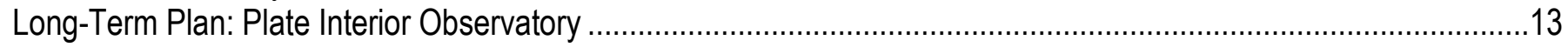

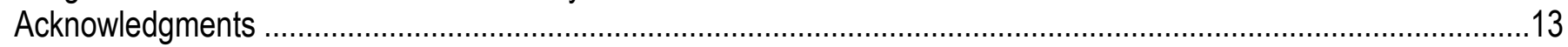

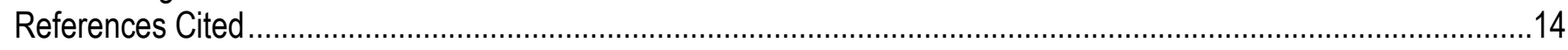

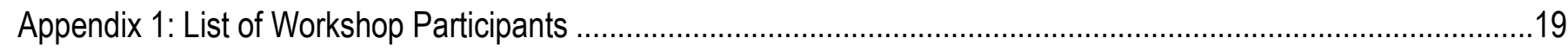

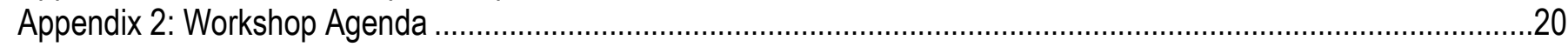

\section{Figure}

Figure 1. Proposed development of midcontinent geodetic networks 


\section{List of Abbreviations and Acronyms}

$\begin{array}{ll}\text { CEUS } & \text { Central and Eastern United States } \\ \text { CGPS } & \text { Continuous Global Positioning System } \\ \text { CORS } & \text { Continuously Operating Reference Stations } \\ \text { CUS } & \text { Central United States } \\ \text { FAA } & \text { Federal Aviation Administration } \\ \text { FEMA } & \text { Federal Emergency Management Agency } \\ \text { GAMA } & \text { Geodetic Array Studies for Mid America } \\ \text { GPS } & \text { Global Positioning System } \\ \text { InSAR } & \text { Interferometric Synthetic Aperture Radar } \\ \text { lidar } & \text { Light Detection and Ranging } \\ \text { NGS } & \text { National Geodetic Survey } \\ \text { NMSZ } & \text { New Madrid Seismic Zone } \\ \text { NOAA } & \text { National Oceanic and Atmospheric Administration } \\ \text { NWS } & \text { National Weather Service } \\ \text { PBO } & \text { Plate Boundary Observatory } \\ \text { PIO } & \text { Plate Interior Observatory } \\ \text { UCERF } & \text { Uniform California Earthquake Rupture Forecast Model } \\ \text { UNVACO } & \text { University NAVSTAR Consortium }\end{array}$




\title{
Advancing Geodesy in the U.S. Midcontinent: Workshop Report
}

\author{
By Michael W. Hamburger, Oliver S. Boyd, Eric Calais, Nancy E. King, and Seth A. Stein
}

\section{Executive Summary}

The workshop on "Advancing Geodesy in the U.S. Midcontinent" was held from October 31 to November 1, 2012, at Northwestern University in Evanston, Illinois. The workshop included 28 participants from academia, government, and private-sector organizations that are involved in research on geodesy and earthquake hazards in the seismically active areas of the U.S. midcontinent (the region of relatively undeformed crust roughly between the Great Plains and Appalachian Mountains). The workshop was intended to provide guidance to the U.S. Geological Survey's (USGS) internal and external Earthquake Hazards research programs in the U.S. midcontinent. The 2012 workshop was developed as a follow-up to the "Workshop on New Madrid Geodesy and Understanding Intraplate Earthquakes," held in Norwood, Massachusetts, in March 2011. The goal of the 2012 workshop was to provide specific recommendations to the USGS on priorities for infrastructure and research investments related to geodesy in the U.S. midcontinent. Participants were asked to share current research and proposals for future research plans, focusing on the following basic and applied science issues:

- Fundamental processes guiding earthquake generation in the New Madrid Seismic Zone and surrounding regions,

- Application of geodetic measurements to assessment of earthquake hazards,

- Optimization of geodetic monitoring networks to constrain crustal deformation, and

- Critical approaches in data analysis, modeling, and interpretation of geodetic data.

Among the outcomes of the workshop was a consensus recommendation for expanding the density, quality, and duration of geodetic observations in the New Madrid Seismic Zone and surrounding regions of active intraplate seismicity in order to better understand processes driving seismogenesis. The recommendations focus on short- and intermediate-term expansion of continuous Global Positioning System (GPS) monitoring of crustal deformation in the midcontinent region, developed in three principal approaches (fig. 1):

Development of a roughly 10-station local continuous GPS (CGPS) network densified/extended across the New Madrid Seismic Zone

Expansion of the regional CGPS network by roughly 40 stations covering the seismically active areas outside the New Madrid Seismic Zone, including

a. Expansion of geodetic observations into the Wabash Valley/Illinois Basin Seismic Zone,

b. Expansion of geodetic observations into the southern New Madrid region, in and around Marianna, Arkansas, and

c. Development of a sparse regional network designed to capture regional deformation rates. 
d. Development of a midcontinent-wide backbone network of highly reliable CGPS stations, drawing from existing Continuously Operating Reference Stations (CORS) and Plate Boundary Observatory (PBO) sites. This can be done at relatively low cost by leveraging existing efforts.

In addition to these short- and intermediate-term recommendations, the group recommends development of a long-term strategic plan directed toward a "Plate Interior Observatory" (PIO) that comprises over 100 stations and will be extended to include active deformation from the eastern seaboard to the Great Plains. This plan will leverage support from major funding agencies in collaboration with other earth science consortia (for example, EarthScope, UNAVCO). The networks may make use of existing CGPS networks (for example, navigation, transportation, or geodetic control networks) and may include transformation of existing campaign geodetic sites to CGPS observation, or development of new CGPS networks. Given the low rates of intraplate deformation in the central United States (CUS), a commitment to a long duration of observation will be required to ensure reliable detection of geodetic signals. Although the focus of the "Advancing Geodesy in the U.S. Midcontinent" workshop was primarily on GPS as a tool for measuring crustal deformation, this report briefly reviews other tools and their potential applicability to geodetic problems in the U.S. midcontinent.

\section{Introduction}

This report summarizes discussions that took place at a community workshop on "Advancing Geodesy in the U.S. Midcontinent" that was held October 31 to November 1, 2012, at Northwestern University in Evanston, Illinois (Ill.). The workshop, which included 28 participants from academia, government, and private sector organizations involved in research on geodesy and earthquake hazards in the seismically active areas of the U.S. midcontinent, was convened to provide guidance to the U.S. Geological Survey's (USGS) Earthquake Hazards Program for both its internal and external research programs on earthquake hazards in the U.S. midcontinent. This report summarizes those discussions and presents some specific recommendations for research priorities for research on active crustal deformation in the U.S. midcontinent. As a working definition, we take the "U.S. midcontinent" to include the relatively undeformed segment of the North American craton extending from the Appalachians to the Great Plains and from the Ouachita orogen to the Great Lakes.

\section{Background and Motivation}

The August 2011 M5.8 Mineral, Virginia earthquake, which shook large areas of the east coast and damaged structures in Washington, D.C. (including the Washington Monument), demonstrated how little is known about the causes of earthquakes in the central and eastern United States and the hazards they pose. At present, no comprehensive model exists to explain such earthquakes. Taken at its simplest, the issue is how forces that we largely do not understand cause motion on faults that have not been identified and create hazards that we cannot easily assess. The earthquakes along these structures can be large. The best known in modern times, the 1929 M7.2 earthquake on the Grand Banks of Newfoundland, caused a large landslide of thick continental slope sediments, which cut trans-Atlantic telegraph cables and generated a tsunami. The resulting 28 fatalities include most of Canada's known deaths from earthquakes. Other notable events include the 1933 M7.3 Baffin Bay earthquake, the 1755 M 6 Cape Ann, Massachusetts (Mass.) earthquake, the 1811-1812 New Madrid sequence of three $\mathrm{M} \sim 7+$ earthquakes, and the $1886 \mathrm{M} \sim 7$ Charleston, South Carolina earthquake.

We do not know whether the presently active zones are active for extended periods of time but lack clear geomorphic expression, or simply represent loci of activity that migrate (Stein and others, 
2009) with individual faults active for short intervals and dormant for long ones (Newman and others, 1999; Crone and others, 2003). This question makes it particularly difficult to assess the extent to which the instrumental record for continents indicates the location of future damaging earthquakes. On one hand, the locations of past small earthquakes are good predictors of the locations of future ones (Kafka, 2007). On the other hand, some models predict that aftershock sequences for large continental earthquakes should continue for hundreds of years (Stein and Liu, 2009). Thus, some present concentrations of seismicity may be "echoes" of large prehistoric earthquakes. However, in the case of the 1811-1812 New Madrid earthquakes, the study by Page and Hough (2014) argues that this is not the case.

Geodesy is a natural approach to exploring these issues. Because it provides an independent measurement of the accumulation of tectonic strain in continental interiors, geodesy may provide direct evidence of the basic cause of intracontinental earthquakes. The feasibility of capturing tectonic strain in continental interiors is illustrated by recent studies using GPS data to map the effects of glacial isostatic adjustment (GIA) (Calais and others, 2006; Sella and others, 2007). The results show that GIA is the predominant deformation process in eastern North America. GPS can resolve even the small motions south of the "hinge line" (approximately at the latitude of the Great Lakes) separating uplift to the north from subsidence to the south. This result also implies that a good knowledge of the GIA signal is necessary in order to extract tectonic deformation from a geodetic velocity field that reflects the combination of both GIA and tectonic deformation. Therefore, the search for regional tectonic signals in the eastern United States requires measurements over a much broader region in order to separate them from the GIA signal.

Although there is general consensus about the recent history of large earthquakes in the U.S. midcontinent, there remains considerable debate about the level of future earthquake hazards facing residents of the CUS. The question of earthquake hazard relies on a fundamental understanding of the processes, observations, and implications of intraplate deformation in North America's continental interior (for example, Newman and others, 1999; Petersen and others, 2014; Calais and Stein, 2009; Frankel and others, 2012). Critical issues that have fueled the debate include the question of the size (Johnston, 1996; Hough and others, 2000; Holzer and others, 2012) and return periods of earthquakes in the New Madrid Seismic Zone (NMSZ) (Newman and others, 1999; Tuttle and others, 2002; Calais and Stein, 2009), as well as the potential for large earthquakes in other areas of the CUS (Kelson and Swan, 1990; Braile and others, 1982, Crone and others, 1997). Earthquake-magnitude estimates for the earthquakes in the 1811-1812 New Madrid sequence range from less than M7.0 to greater than M8.0; recurrence estimates range from as little as 160 to as many as 10,000 or more years (yr). Paleoseismic data from earthquake zones outside the NMSZ, such as the Wabash Valley Seismic Zone, record large past earthquakes (Obermeier and others, 1991; Munson and others, 1997), yet the size and recurrence intervals remain poorly constrained. These uncertainties have a profound effect on seismic-hazard estimates (Petersen and others, 2014) and in turn affect the costs associated with adopting differing levels of earthquake-resistant construction and the potential loss of life and extent of economic hardship (Stein, 2010).

Because the driving force of crustal seismicity - at least at plate boundaries - is the accumulation of tectonic strain along active faults, observations of geodetic strain are critical to understanding earthquake-generation processes and their manifestation in the earthquake record. Unfortunately, both the historical and paleoseismic record of seismicity remain insufficient to reasonably constrain fault slip rates and earthquake potential in many seismically active zones. For these reasons, we have seen considerable growth in the use of geodetic methods for improving earthquakehazard estimation. In other areas where geodetic techniques have been applied, zones of high crustal 
strain rates are known to be associated with significant seismic energy release. Conversely, areas of low strain tend to have lower seismic potential (for example, Savage, 1983). Where the surface strain can be used to map strain on locked fault zones, these geodetic measurements can be specifically tied to earthquake strain accumulation and potential for future earthquakes (for example, Bürgmann and others, 2000b; Fialko, 2006). However, the specific application of strain measurements to probabilistic seismichazard assessment remains controversial, largely because of the variability in quality and distribution of geodetic data and because its contribution to hazard estimation relies on specific mechanical models that remain poorly constrained.

The USGS Uniform California Earthquake Rupture Forecast, Version 2 (UCERF 2) (Field and others, 2009) and its successor, UCERF 3 (Working Group on California Earthquake Probabilities, 2011) are now explicitly incorporating geodetically determined strain rates to constrain earthquakerecurrence intervals in the seismically and tectonically active plate boundary zone of California. The models generally rely on kinematic inversion of observed GPS velocities to infer both fault-related and off-fault strain accumulation. This approach is beginning to extend to other parts of the country, for instance in the Intermontane West and Wasatch fault regions of Utah and Nevada (M. Petersen, USGS, oral commun., 2013).

The introduction of high-precision geodetic techniques to the CUS promises a powerful, independent observational tool to help address issues of earthquake hazard in the region. Yet, while geodetic observations and modeling are now widely used in plate-boundary environments, they have seen only limited application to intraplate environments, where strain rates are low and where, even under ideal conditions, signals may be exceeded by measurement errors for long periods of observation (Calais and Stein, 2009).

Historically, application of geodetic methods to earthquake hazards in the CUS has been particularly problematic. Because the signals are relatively small, the geodetic noise (largely associated with near-surface noise and poor monumentation) relatively large, and the station spacing sparse, the history of geodetic analysis has been rife with conflicting conclusions. Initial estimates of high strain rate (albeit with large uncertainty) in the New Madrid Zone (Liu and others, 1992) were not supported by subsequent measurements (Weber and others, 1998; Newman and others, 1999). Measured regional surface strains have been exceptionally low, on the order of $10^{-9}$ per yr or less (Calais and Stein, 2009). More recent analysis of the same data, however, suggests that strains local to some areas within the NMSZ are an order of magnitude higher than seen regionally (Frankel and others, 2012). A decade of campaign-based GPS measurements in the Illinois Basin region (Galgana and Hamburger, 2010) suggests marginally significant strain rates, on the order of $1-2 \times 10^{-9} \mathrm{yr}^{-1}$.

Such low strains, coupled with moderate amounts of noise, require some combination of dense arrays, stable monumentation, and long periods of observation. Recent seismic studies of the NMSZ indicate the existence of a pronounced mantle low-velocity zone (Bedle and van der Lee, 2006; Zhang and others, 2009; Pollitz and Mooney, 2013), suggesting a volume that is weaker than the surrounding mantle and thus may concentrate stresses. Hence, even low strains may be focused within the NMSZ, making the measurement of these strains an even higher priority.

\section{Geodetic Methods}

The workshops described in this report addressed a number of issues critical to the success of geodetic research in the U.S. midcontinent. Although the focus of the discussions at the Norwood and Evanston workshops was primarily on GPS measurements and their implications for earthquake hazard research, we briefly review the predominant geodetic methods and their applicability to midcontinent geodynamic research. 


\section{Global Positioning System}

For the past three decades, the GPS system has provided a reliable, low-cost approach for highprecision measurements of crustal deformation (for example, Dixon, 1991; Segall and Davis, 1997). The GPS system provides high-precision estimates of 3D surface site positions within a stable global reference frame. Because GPS relies on satellite-generated, microwave-frequency electromagnetic signals, it can be used under virtually any meteorological conditions and does not require inter-visibility of neighboring geodetic sites. The relatively low cost and high precision make it ideally suited for geodynamic studies of crustal strain. Measurement networks can be designed to maximize the number and spatial distribution of GPS stations (typically using episodic measurements at campaign-based networks of geodetic benchmarks) or to maximize GPS precision (typically at sparser networks of continuously operated GPS receivers). In some cases, GPS networks can balance precision and network density using a hybrid "semi-permanent" deployment model (Blewitt and others, 2009). Measurement precision depends strongly on the deployment strategy, but under ideal conditions, site positions can be estimated to an accuracy of 1-2 millimeters ( $\mathrm{mm}$ ) (horizontal), corresponding to velocity uncertainties (depending on network observation duration and monumentation) of fractions of a millimeter per year.

\section{Interferometric Synthetic Aperture Radar}

Although less precise than GPS measurements, Interferometric Synthetic Aperture Radar (InSAR) provides a spatially continuous estimate of the surface deformation field (for example, Bürgmann and others, 2000a). InSAR has been widely used as one of a number of applications for noninvasive study of earthquake, volcanic, and anthropogenic surface deformation (Snieder and others, 2007). Although it has traditionally been less applicable in areas of anthropogenic land use, a variety of new techniques, such as persistent scatterer analysis, allows high-precision measurements to be obtained even in areas of highly disrupted cultural land use. Because the precision of InSAR is nearly an order of magnitude lower than that of GPS, however, it is not widely applicable to the low signal-to-noise environment of intraplate tectonism. However, it has found significant value in analysis of coseismic surface deformation associated with moderate or large earthquakes in intraplate zones (for example, Schmidt and Bürgmann, 2007), and thus could have significant potential for future earthquakes in the U.S. midcontinent. InSAR may also be useful for separating deformation associated with regional tectonic processes from those associated with anthropogenic sources, such as groundwater withdrawal (Snieder and others, 2007).

\section{Light Detection and Ranging}

Light Detection and Ranging (lidar) encompasses a suite of powerful new remote-sensing techniques that permit retrieval of surface topography, and in some cases, crustal deformation, even in the presence of significant vegetation. Both ground-based and airborne-based lidar methods have been applied to geodynamic research. Of particular interest is the ability to numerically remove vegetation from imagery to produce "bare-earth" ground models. It has found widespread application to the study of active fault zones (for example, Meigs, 2013), particularly in plate boundary environments (for example, Borsa and Minster, 2012; Salisbury and others, 2012; Duffy and others, 2013). Following identification of active faults in urban areas of the Pacific Northwest (for example, Haugerud and others, 2001), similar applications have been developed in the CUS. The USGS funded and coordinated the acquisition of roughly 722 square kilometers of lidar data and derivative bare-earth ground models to support earthquake hazard studies in the NMSZ. The study area includes coverage of the Commerce Geophysical lineament, Crowley's Ridge, and features in and near the St. Francis River 
(http://opentopo.sdsc.edu/gridsphere). These data are in preliminary stages of analysis, and have not yet found their way into the scientific literature.

\section{Anticipated Contribution to USGS Strategic Planning}

The USGS Earthquake Hazards Program promotes research to improve our understanding of earthquake hazards. This can occur through internal research programs, and through funding of external research grants and cooperative monitoring networks. For example, the USGS Earthquake Hazards Program provided most of the support for the Geodetic Array Studies for Mid America GPS network in the NMSZ and has supported campaign-based GPS observations elsewhere in the U.S. midcontinent (for example, Illinois Basin geodetic network [Hamburger and others, 2002; Galgana and Hamburger, 2010]).

Each year, the USGS Earthquake Hazards Program requests research proposals to advance our state of understanding in specific geographic areas, such as the central and eastern United States (CEUS), and in disciplines including earthquake effects and earthquake physics. Current significant research problems and recommendations by the research community form the basis for USGS strategic planning regarding earthquake hazards. For example, two themes for CEUS research that were a direct result of the 2011 and 2012 workshops are:

- Proposals to improve the quality of geodetic data and networks in the CUS are encouraged, particularly if they are the outgrowth of a community-based plan for the New Madrid region and the CUS. These studies may include the development of a comprehensive set of precise geodetic measurements that could provide: (1) baseline measurements prior to any future earthquake in the region, (2) re-measurements of existing networks (for example, in New Madrid, Wabash Valley, and Charleston), (3) improvement of monumentation for existing networks (for example, CORS, National Geodetic Survey [NGS], and the Federal Aviation Administration [FAA]), and (4) continuous monitoring of data quality at existing GPS networks.

- Development of synoptic, physical models of long-term deformation in intraplate areas including both onshore and offshore areas of the CEUS and the NMSZ are encouraged. Proposals may seek to address topics such as the cause of large earthquakes, regional migration of seismicity and earthquake clustering as suggested by paleoseismological results, and interaction of known geological structures within the tectonic stress field. Coordination with EarthScope research projects is particularly encouraged.

We envision that results from the 2012 workshop will lead to research and recommendations that will further shape USGS priorities with respect to geodetic monitoring and modeling, especially as they pertain to seismic hazards in the CEUS. Although the workshop was primarily focused on scientific targets of current and future midcontinent geodetic research, we recognize that there are many stakeholders, both within and outside the scientific community, for whom this research may make critical contributions. This includes other government agencies that directly or indirectly make use of geodetic data (National Geodetic Survey, Federal Aviation Administration, National Oceanic and Atmospheric Administration [NOAA], National Weather Service [NWS]), public- and private-sector organizations that make use of geodetic data for surveying (for example, government and commercial survey community), and organizations that will benefit from scientific results of geodetic research (for example, FEMA, state and local emergency management organizations, regional planning organizations, and insurance and engineering industry). We anticipate an increase in opportunities for research partnerships, funding opportunities, and public-private partnerships that can enhance future geodetic research. 


\section{The 2011 Norwood Workshop}

The controversy surrounding the question of New Madrid earthquake hazard and the potential for new approaches through geodetic data analysis led the scientific community to organize for a review of existing geodetic data and its meaning for continued New Madrid seismicity. In March 2011, a geodesy workshop, organized by Oliver Boyd, Eric Calais, John Langbein, Harold Magistrale, Seth Stein, and Mark Zoback, and funded by FM Global, took place in Norwood, Mass. A group of 26 researchers met for a one-day workshop to discuss our current state of knowledge regarding earthquake return periods, seismic hazard, active tectonics, and geodetic infrastructure and models in the NMSZ. Specifically, the group addressed the challenge of reconciling present-day geodetic measurements with paleoseismically derived earthquake rates. The workshop was summarized in an EOS article (Boyd and Magistrale, 2011) and a USGS Open-File Report (Boyd and others, 2013).

Among the observations summarized at the workshop were:

- There is a fundamental disagreement between paleoseismic estimates for recurrence of New Madrid earthquakes (roughly $500 \mathrm{yr}$, Tuttle and others [2002]) and estimates based on regional strain-rate accumulation, which imply a return period of at least 10,000 yr for M7 events with 2 meters of average slip (Calais and Stein, 2009).

- The relative motions between most of the 55 GPS station pairs in the NMSZ are less than roughly $0.2 \mathrm{~mm} / \mathrm{yr}$ and that the uncertainties are probably on the order of $0.2 \mathrm{~mm} / \mathrm{yr}$ (Calais and Stein, 2009).

- Two baselines within the NMSZ show potentially significant relative motions of roughly $0.3-0.4$ $\mathrm{mm} / \mathrm{yr}$. There remains disagreement as to whether these signals reflect a physical process associated with strain accumulation on New Madrid faults (for example, Frankel and others, 2012), or aberrant measurements that represent part of the statistically expected range of geodetic noise.

- There appears to be no difference in the orientation of principal stresses in the NMSZ with that of the surrounding region (Hurd and Zoback, 2012). Thus, the stress state in this region results from the same large-scale geologic processes stressing the central and eastern United States.

- Active faults in the NMSZ appear to have frictional strength similar to faults throughout the region, and limited available heat flow data do not show the NMSZ to be warmer (and thus weaker) than its surroundings (McKenna and others, 2007).

- There is evidence for marginally significant geodetic strain accumulation in the northern periphery of the NMSZ, including the southern Illinois Basin and the Wabash Valley seismic zone (Galgana and Hamburger, 2010).

Models that relate low long-term strain to the occurrence of earthquakes in the NMSZ were presented and discussed and include those that invoke mantle convection (Forte and others, 2007), glacial isostatic adjustment (Grollimund and Zoback, 2001), crustal heterogeneity (Kenner and Segall, 2000; Pollitz and others, 2001), and erosion following retreat of the glaciers (Calais and others, 2010). These processes may be responsible for the continued triggering of, rather than restoring the energy needed for, repeated large earthquakes. Furthermore, some researchers hypothesize that the next large earthquakes could occur on other faults in the region based on observations of earthquake migration in China and models of stress evolution following the 1811-1812 earthquakes (Li and others, 2005; Liu and others, 2011).

Although there remains considerable uncertainty as to the ultimate driving force of these intraplate earthquakes, it is reasonable to expect that processes responsible for strain accumulation prior to 1811-1812 are still active today. Attendees concurred that the current density of geodetic monitoring 
is inadequate to address the apparent discrepancy between models inferred from geodetic and geologic data. There was general agreement on the need for densification of geodetic monitoring in key locations by a combination of continuous and less-expensive periodic campaign GPS deployments. Specific configurations were discussed by John Langbein in the 2013 Open-File Report detailing the 2011 workshop (Boyd and others, 2013). In conjunction with improved geodetic monitoring, attendees argued that new physically based models of intraplate seismogenesis and data that constrain intraplate earthquake generation and recurrence are needed.

Although the Norwood workshop was highly successful in identifying critical scientific and technical issues, the short duration of the meeting proved to be insufficient to lead to consensus recommendations on implementation of geodetic infrastructure in the midcontinent region. It was this goal that led to the continuation workshop effort in Evanston, Ill., in October 2012.

\section{The 2012 Evanston Workshop}

The U.S. Geological Survey provided support for a 2012 follow-up workshop, with a goal of providing guidance to the USGS National Earthquake Hazards Reduction Program for both its internal and external research programs on earthquake hazards in the Midwest. The workshop, entitled "Advancing Geodesy in the U.S. Midcontinent" was held October 31 to November 1, 2012, at Northwestern University in Evanston, Ill. The workshop was organized by Michael Hamburger (Indiana University), Oliver Boyd (USGS), Eric Calais (Purdue University), Nancy King (USGS), and Seth Stein (Northwestern University). The workshop included 28 participants from academia, government, and private-sector organizations involved in geodesy and earthquake hazards in the seismically active areas of the U.S. midcontinent. A list of participants is included in Appendix 1 and the workshop agenda in Appendix 2.

Workshop participants were asked to share current research and proposals for future research plans, focusing on the following basic and applied science themes:

- Fundamental processes guiding earthquake generation in New Madrid and surrounding regions,

- Application of geodetic measurements to assessment of earthquake hazards,

- Optimization of geodetic monitoring networks to constrain crustal deformation, and

- Critical approaches in data analysis, modeling, and interpretation of geodetic data.

The workshop was centered around four focused sessions addressing interconnected scientific themes associated with midcontinent geodesy and deformation; participants were asked to address a series of core scientific questions, as summarized below:

Session 1: Structural and Neotectonic Context

- What do we know about midcontinent geological evolution and structure that is relevant to current deformation in the midcontinent?

- How does our knowledge about paleoearthquakes in the New Madrid and broader region inform models of crustal deformation?

Session 2: Models for Intraplate Seismogenesis

- What drives midcontinent deformation and earthquakes? What do mechanical models tell us about intraplate deformation and earthquakes in the New Madrid and broader region? What additional constraints are needed?

Session 3: Geodetic infrastructure and observations

- What do we know about spatial and temporal patterns of deformation in the midcontinent? What is needed to make progress?

Session 4: Geodetic Applications to Hazard Estimation 
- How do current data on deformation in the New Madrid and broader region inform earthquake hazard assessment and what additional information is needed to improve that assessment?

The structure of the workshop was designed to encourage short, provocative presentations and maximize time for informal group discussion of scientific and technical issues. Breakout sessions were focused on recommendations for geodetic infrastructure to address the scientific issues raised in the introductory sessions.

\section{Research and Modeling}

The workshop addressed a number of issues critical to the success of geodetic research in the U.S. midcontinent. Research to better understand the link between processes driving seismogenesis and observed crustal deformation is needed to help guide the acquisition of data. Several synoptic models exist to explain ongoing earthquakes in the NMSZ (for example Kenner and Segall, 2000; Grollimund and Zoback, 2001; Pollitz and others, 2001; Forte and others, 2007; Calais and others, 2010), but additional research is needed to relate crustal deformation resulting from these models and observed motions.

\section{Geodetic Research Targets and Network Design}

The workshop also examined a number of issues critical to the success of geodetic experiments in the U.S. midcontinent. The focus of the discussions was on approaches to maximize the scientific value of future investments in GPS infrastructure and research. Given the primary emphasis on measurement of tectonic deformation as it relates to earthquake potential, two critical concerns are: (1) selection of geodetic measurement sites where one expects the greatest probability of measuring a tectonic deformation signal and (2) choosing a benchmark location and configuration that maximizes geodetic signal and minimizes noise. Tectonic deformation can result from several processes occurring within and beneath the crust. Forces acting from the sides and below, such as slab pull, ridge push, and mantle drag, can lead to broad continent-wide deformation (Zoback and others, 1989), which can be modulated by heterogeneities of crustal strength and heterogeneities in boundary forces. Viscous forces within the upper mantle, for example, caused by the sinking of remnant subducted lithosphere (Forte and others, 2007), can generate broad regional deformation signals on the Earth's surface. Unstable density anomalies within the lithosphere, under appropriate conditions (Pollitz and others, 2001), can lead to relatively localized deformation at the Earth's surface. Earth-surface processes, such as the melting of glaciers (Grollimund and Zoback, 2001) and rapid erosion of sediment (Calais and others, 2010) can cause regional and relatively localized crustal strain that can persist for thousands of years. Lastly, the stressing of preexisting basement faults, formed as a result of late Precambrian and early Paleozoic tectonic activity, may be manifested as a complex of conjugate normal, reverse, and strikeslip structures at depth (Van Arsdale and Cupples, 2013). These faults may creep at depth yielding a measureable strain rate signal at the surface (Frankel and others, 2012). When the faults fail in an earthquake, the surrounding rock is stressed and will relax over time ( $\mathrm{Li}$ and others, 2005). This leads to measureable surface strain.

Considering these geodynamic processes, the workshop examined a number of scenarios in which to place stations to maximize the success of geodetic experiments. Stations could be placed: (1) across boundaries of significant crustal heterogeneity and within regions of weak crust, (2) in broad transects across regions of proposed significant lateral deformation due to mantle-driven deformation, 
(3) in arrays that capture proposed deformation signals from Earth surface processes, and (4) across active faults.

Attendees concurred that the current density of high-quality stations in the NMSZ is inadequate to properly estimate motions on finite sections of faults that may be creeping at depth (see "Proposed Network Design" section). Other regions recognized as sites of prehistoric earthquakes, for example, Wabash Valley, southern New Madrid (near Marianna, Arkansas), have few or no geodetic stations of appropriate quality with which to analyze surface strain. Attendees suggested that CGPS stations could be added by adopting stations from CORS and upgrading the quality of the geodetic monumentation. Ideally, stations would be located on bedrock, but this is not possible within the Mississippi embayment. With evidence that high-frequency geodetic noise represents a combination of uncorrelated (white) and correlated (flicker and random-walk) noise (for example, Langbein and Johnson, 1997; Mao and others, 1999), a combination of increased station density and extended observation periods is needed to yield more reliable estimates of long-term site velocities and spatial variations in surface strain (Boyd and others, 2013).

Network design may also be informed by models of crustal heterogeneity based on newly available geophysical data sets. EarthScope's USArray is providing an unprecedented volume of seismic data with which to image the lithosphere beneath the United States. For example, this data set could be used to estimate the depth of the Moho and lithosphere-asthenosphere boundaries from receiver functions (for example, Kumar and others, 2012) and seismic wavespeed and attenuation from tomographic methods (for example, Buehler and Shearer, 2012). In conjunction with existing aeromagnetic, gravity, and magnetotelluric data sets, a relatively detailed model of lithospheric strength could result. Given boundary forces, a model of expected crustal strain could then be developed, and, if warranted, stations placed to test and refine this model. Improved modeling of local sources of loading - including the role of deglaciation (Grollimund and Zoback, 2001), intracrustal heterogeneity (Kenner and Segall, 2000; Pollitz and others, 2001), erosion of surficial sediment (Calais and others, 2010), and shorter term hydrological loading (for example, Costain and Bollinger, 2010) — are critically needed to inform the design of geodetic networks. Additional CGPS sites in the region are also of interest to study these loading processes. These observations can, in turn, be used to infer rheological properties of the lithosphere in the region.

\section{Proposed Network Design}

The primary outcome of the workshop was a consensus recommendation for expanding geodetic observations in the New Madrid and surrounding regions of active intraplate seismogenesis. The recommendations focus on expansion of CGPS monitoring of crustal deformation in the midcontinent region, developed in three principal approaches (fig. 1):

1. Development of a roughly 10-station CGPS network densified/extended across the NMSZ.

2. Expansion of the regional CGPS network by roughly 40 continuous stations expanded to seismically active areas outside the NMSZ, including:

- Expansion of geodetic observations into the Wabash Valley/Illinois Basin seismic zone,

- Expansion of geodetic observations into the southern New Madrid region, and

- Development of a sparse regional network designed to capture regional deformation rates. 
3. Development of a midcontinent-wide backbone network of highly reliable CGPS stations, drawing from existing CORS and PBO sites, and augmenting with new sites where necessary. This can be done at very low cost by leveraging existing efforts.

In addition to these short- and intermediate-term recommendations, the group recommends collaborative development of a long-term strategic plan directed toward a PIO that comprises over 100 stations and will be extended to include active deformation from the Eastern Seaboard to the Great Plains, leveraging support from major funding agencies in collaboration with other earth science consortia (for example, EarthScope and UNAVCO).

High priority was given to expansion of the current New Madrid GPS network (Approach 1 above). Additional, high-quality CGPS sites are needed to help confirm or refute the presence of significant geodetic signals associated with strain accumulation along the New Madrid fault system. Particular attention will need to be paid to monumentation to minimize near-surface geodetic noise. The networks may also benefit by maximizing use of existing CGPS networks (for example, navigation, transportation, or geodetic control networks), upgrading existing CGPS networks, and transforming existing geodetic monuments to CGPS observation.

An expansion of GPS networks should be designed to address earthquake potential in areas adjacent to the NMSZ. The primary focus of this expansion would be to provide improved geodetic coverage of areas of current seismic activity (for example, Wabash Valley Seismic Zone), areas of proposed recurrent basement faulting (for example, Reelfoot South Fault Zone [Csontos and others, 2008; Van Arsdale and Cupples, 2013), Meeman-Shelby Fault Zone (Odum and others, 2010; Hao and others, 2013]), and areas with demonstrated history of paleoseismic events (for example, Wabash Valley Seismic Zone [Munson and others, 1997], Marianna, Arkansas zone [Tuttle and others, 2006], and Saline River Fault Zone [Cox and others, 2010]). Because the records of both basement faulting and paleoseismicity are incomplete, the group also recommended inclusion of a sparse, regional network to capture background regional strain and possible localized strain outside of known target areas. The group recommended, as a lower priority, continued monitoring of existing campaign GPS networks (for example, New Madrid and Illinois Basin networks) and exploration of 'hybrid' networks that incorporate the benefits of high-quality monumentation and the flexibility and low-cost of episodic or 'semi-permanent' GPS observations (for example, Blewitt and others, 2009). Improvements in analysis of stability of geodetic monumentation in areas of thick unconsolidated sediment (for example, Mattioli and Jansma, 2007) are critically needed to advance the reliability of geodetic measurements in the New Madrid region. Taking advantage of the expertise attained through the PBO project, a partnership with the UNAVCO consortium could play a key role in ensuring quality in installation, status monitoring, data integrity, and data processing. An example of a possible configuration of an expanded midcontinent GPS network, including a 10-station New Madrid network and a 40-station regional GPS network, is shown in figure 1. 


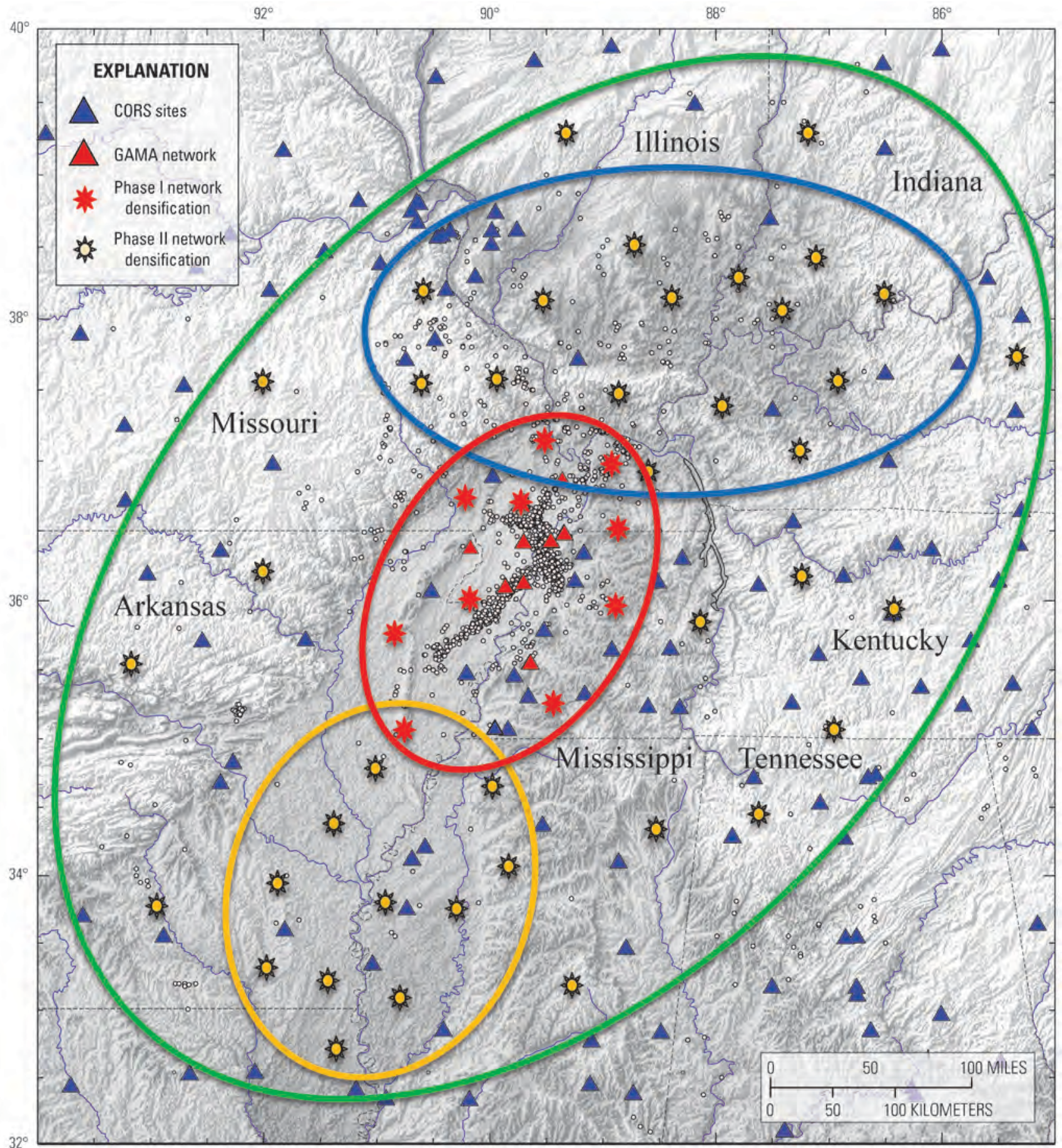

Figure 1. Proposed development of midcontinent geodetic networks. Solid blue and red triangles show existing continuous GPS (CGPS) stations operated as part of the Continually Operating Reference Stations (CORS) and Geodetic Array Studies for Mid America (GAMA) networks, respectively. Red and yellow stars show generalized distribution of proposed sites for CGPS in Phase I (New Madrid densification) and Phase II (regional strain monitoring) respectively. Ellipses show generalized areas proposed for network expansion: red = New Madrid region; blue = Wabash Valley Seismic Zone; yellow = southern New Madrid extension; green = regional strain monitoring network. Base-map is 3-arc second topography available from the USGS at http://ned.usgs.gov/index.html. 


\section{Geodetic Data Analysis}

An essential component of any future expansion of geodetic networks in the U.S. midcontinent is a plan for geodetic data archiving and analysis. Because the signal of intraplate deformation is so small, the introduction of systematic errors in GPS data processing could have significant potential impact on the results and interpretation (for example, Stein, 2007). For that reason, it would be beneficial to subject all midcontinent geodetic data to multiple streams of analysis. Large-scale dataprocessing centers offer the benefit of consistent data processing, in the same reference frame, and potentially provide daily time series, short-term kinematic results, and average station velocities in numerical and graphical form. Among the data-analysis centers that could potentially provide this service are the USGS Earthquake Hazards Program (http://earthquake.usgs.gov/monitoring/gps/), the UNAVCO PBO data processing facility (http://pbo.unavco.org/data/gps), the Scripps Orbit and Permanent Array Center (http://sopac.ucsd.edu/processing/), and the Nevada Geodetic Laboratory (http://geodesy.unr.edu/). Any of these network processing centers could be easily adapted to add new stations to the system and process them at minimal cost. In addition, it is important that a rigorous comparison of complementary data-analysis products be performed, with a thorough investigation of position time series, in order to reduce ambiguity in identifying the signals of tectonic origin. This postprocessing stage should benefit from solutions from the large-scale data-processing centers mentioned above as well as from solutions from individual investigators. The end product would be a verified, combined, velocity solution expressed in a well-defined geodetic frame.

\section{Long-Term Plan: Plate Interior Observatory}

A long-term strategy that was supported by participants at the Evanston Workshop is a goal to develop a CGPS PIO that comprises over 100 stations (comparable to the EarthScope PBO) which would provide the necessary infrastructure to study active deformation from the eastern seaboard to the Great Plains. Such an effort could leverage support from major funding agencies in collaboration with other earth science consortia (for example, EarthScope and UNAVCO) and NOAA/NGS. The resulting data would have much better resolution of the anticipated slow deformation than possible with present NOAA CORS sites. PIO and CORS data could be processed as part of the PBO data analysis, providing a publicly available, consistent velocity field. CORS and PBO sites will give insight into the quality of CORS data. As the GIA studies show, using careful quality control to reject poor data yields high quality velocity fields from the CORS data.

The velocity field, together with earthquake, geological, and geomorphological data (for example, Pazzaglia and others, 2010) would be analyzed using a new generation of tectonic models (for example, Ghosh and Holt, 2012) to constrain the dynamics of short- and long-term local and regional deformation processes. The practicality of doing so is shown by the fact that the GPS velocities are already being used to improve models of mantle viscosity (Peltier and Drummond, 2008), which controls the response to ice loads. We believe that such a large-scale effort is essential to provide both the spatial coverage and geodetic resolution necessary to resolve fundamental scientific problems associated with the generation of earthquakes in North America's continental interior.

\section{Acknowledgments}

We gratefully acknowledge the reviews of Bill Leith, Ed Nissen, and Rob Williams, and the constructive input from workshop participants. Indiana University Department of Geological Sciences and Northwestern University Department of Earth and Planetary Sciences provided various types of 
support that helped make this workshop a success. The workshop was funded by USGS Grant \#G12AC20026.

\section{References Cited}

Bedle, Heather, and van der Lee, Suzan, 2006, Fossil flat-slab subduction beneath the Illinois Basin, USA: Tectonophysics, v. 424, p. 53-68.

Blewitt, Goeffrey, Hammond, W.C., and Kreemer, Corné, 2009, Geodetic observation of contemporary deformation in the northern Walker Lane-1. Semipermanent GPS strategy: Geologic Society of America Special Paper 447, p. 1-15.

Borsa, A.A., and Minster, J.B., 2012, Rapid determination of near-fault earthquake deformation using differential LiDAR: Bulletin of the Seismological Society of America, v. 102, no. 4, p. 1,335-1,347, doi:/10.1785/0120110159.

Boyd, O.S., and Magistrale, Harold, 2011, Studying geodesy and earthquake hazard in and around the New Madrid Seismic Zone-Meeting report: Eos Transactions American Geophysical Union, v. 92, no. 38 , p. 317.

Boyd, O.S., Calais, Eric, Langbein, John, Magistrale, Harold, Stein, S.A., and Zoback, Mark, 2013, Workshop on New Madrid geodesy and the challenges of understanding intraplate earthquakes: U.S. Geological Survey Open-File Report 2013-1004, 184 p.

Braile, Larry, Hinze, W.J., Keller, G.R., and Lidiak, E.G., 1982, The northeastern extension of the New Madrid Seismic Zone, in Investigations of the New Madrid, Missouri, Earthquake Region, McKeown, F.A., and Pakiser, L.C., eds.: U.S. Geological Survey Professional Paper 1236, p. 175-184.

Buehler, J.S., and Shearer, P.M., 2012, Localized imaging of the uppermost mantle with USArray Pn data: Journal of Geophysical Research, v. 117, B09305, doi:10.1029/2012JB009433.

Bürgmann, Roland, Rosen, P.A., and Fielding, E.J., 2000a, Synthetic aperture radar interferometry to measure earth's surface topography and its deformation: Annual Review of Earth and Planetary Sciences, v. 28, p. 169-209.

Bürgmann, Roland, Schmidt, Dominic, Nadeau, R.M., d’Alessio, M.A., Fielding, E.J., Manaker, D.M., McEvilly, T.V., and Murray, M.H., 2000b, Earthquake potential along the northern Hayward fault, California: Science, v. 289, no. 5482, p. 1,178-1,182.

Calais, Eric, Han, J.Y., DeMets, Chris, and Nocquet, J.M., 2006, Deformation of the North American plate interior from a decade of continuous GPS measurements: Journal of Geophyical Research, v. 111, doi:10.1029/2005JB004253.

Calais, Eric, and Stein, S.A., 2009, Time-variable deformation in the New Madrid Seismic Zone: Science, v. 323, no. 5920, p. 1,442-1,442.

Calais, Eric, Freed, A.M., Arsdale, R.V. , and Stein, S.A., 2010, Triggering of New Madrid seismicity by late-Pleistocene erosion: Nature, v. 466, p. 608-611.

Costain, J.K., and Bollinger, G.A., 2010, Review-Research results in hydroseismicity from 1987 to 2009: Bulletin of the Seismological Society of America, v. 100, p. 1,841-1,858.

Cox, R.T., Gordon, Joshua, Forman, S.L., Brezina, Thomas, Negrau, Mircea, Hill, Arleen, Gardner, Christopher, and Machin, Sarah, 2010, Paleoseismic sand blows in north Louisiana and south Arkansas: Seismological Research Letters, v. 81, p. 1,032-1,047.

Crone, A.J., Machette, M.N., Bradley, L-A., and Mahan, S.A., 1997, Late Quaternary surface faulting on the Cheraw fault, southeastern Colorado: U.S. Geological Survey Miscellaneous Geologic Investigations I-2591, 7 p. pamphlet, 1 plate. 
Crone, A.J., De Martini, P.M., Machette, M.N., Okumura, Koji, and Prescott, J.R. 2003, Paleoseismicity of two historically quiescent faults in Australia-Implications for fault behavior in stable continental regions: Bulletin of the Seismological Society of America, v. 93, p. 1,913-1,934.

Csontos, Ryan, Van Arsdale, R., Cox, R.T., and Waldron, Brian, 2008, The Reelfoot Rift and its impact on Quaternary deformation in the central Mississippi River Valley: Geosphere, v. 4, p. 145-158.

Dixon, T.H., 1991, An introduction to the global positioning system and some geological applications: Reviews of Geophysics, v. 29, no. 2, p. 249-276, doi:10.1029/91RG00152.

Duffy, Brendan, Quigley, Mark, Barrell, D.J.A., Van Dissen, Russ, Stahl, Timothy, Leprince, Sébastien, McInnes, Craig, and Bilderback, Eric, 2013, Fault kinematics and surface deformation across a releasing bend during the 2010 MW7.1 Darfield, New Zealand, earthquake revealed by differential lidar and cadastral surveying: Geological Society of America Bulletin, v. 125, no. 3-4, p. 420-431, doi:10.1130/B30753.1.

Fialko, Yuri, 2006, Interseismic strain accumulation and the earthquake potential on the southern San Andreas Fault system: Nature, v. 441, p. 968-971.

Field, E.H., Dawson, T.E., Felzer, K.R., Frankel, A.D., Gupta, V., Jordan, T.H., Parsons, Thomas, Petersen, M.D., Stein, R.S., Weldon, R.J., Wills, C.J., 2009, Uniform California earthquake rupture forecast, version 2 (UCERF 2): Bulletin of the Seismological Society of America, v. 99, p. 2053-2107.

Forte, A.M., Mitrovica, J.X., Moucha, Robert, Simmons, N.A., and Grand, S.P., 2007, Descent of the ancient Farallon slab drives localized mantle flow below the New Madrid Seismic Zone: Geophysical Research Letters, v. 34, doi:10.1029/2006GL027895.

Frankel, Art, Smalley, Robert, and Paul, John, 2012, Significant motions between GPS sites in the New Madrid region: Implications for seismic hazard: Bulletin of the Seismological Society of America, v. 102 , p. 479-489.

Galgana, G.A., and Hamburger, M.W., 2010, Geodetic observations of active intraplate crustal deformation in the Wabash Valley seismic zone and the southern Illinois Basin: Seismological Research Letters., v. 81, p. 699-714.

Ghosh, Attreyee, and Holt, W.E., 2012, Plate motions and stresses from global dynamic models: Science, v. 335, p. 839-843.

Grollimund, Balz, and Zoback, M.D., 2001, Did deglaciation trigger intraplate seismicity in the New Madrid Seismic Zone?: Geology, v. 29, p. 175-178.

Michael W.H., Vladimir Rybakov, Anthony Lowry, Bingming Shen-Tu, 2002, Preliminary Results from a GPS Geodetic Network in the Southern Illinois Basin: Seismological Research Letters., v. 73, p. 762-775.

Hao, Yanjun, Magnani, M.B., McIntosh, Kirk, Waldron, Brian, and Guo, Lei, 2013, Quaternary deformation along the Meeman-Shelby fault, near Memphis, Tennessee imaged by high-resolution marine and land seismic reflection profiles: Tectonics, v. 32, p. 1-15.

Haugerud, R.A., Weaver, C.S., and Harless, Jerry, 2001, Finding faults with LIDAR in the Puget Lowland: Seismological Research Letters, v. 72, no. 2, p. 253.

Holzer, T.L., Noce, Thomas, and Bennett, M.J., 2012, Liquefaction evidence for large magnitudes of the 1811-1812 New Madrid earthquakes [abstract]: Geological Society of America Absracts with Program, v. 44, no. 7, p. 291.

Hough, S.E., Armbruster, J.G., Seeber, Leonardo, and Hough, J.F., 2000, On the Modified Mercalli intensities and magnitudes of the 1811-1812 New Madrid earthquakes: Journal of Geophysical Research, v. 105, 23,839-23,864. 
Hurd, Owen, and Zoback, M.D., 2012, Regional stress orientations and slip compatibility of earthquake focal planes in the New Madrid Seismic Zone: Seismological Research Letters, v. 83, p. 672-679, doi:10.1785/0220110122 .

Johnston, A.C., 1996, Seismic moment assessment of earthquakes in stable continental regions-III. New Madrid 1811-1812, Charleston 1886 and Lisbon 1755: Geophysical Journal International, v. 126, p. 314-344.

Kafka, Alan, 2007, Does seismicity delineate zones where future large earthquakes are likely to occur in intraplate environments?, in Continental intraplate earthquakes-Science, hazard, and policy issues, Stein, S., and Mazzotti, S., eds: Geological Society of America Special Paper 425, p. 35-48.

Kelson, K.I., and Swan, F.H., 1990, Paleoseismic history of the Meers fault, southwestern Oklahoma, and implications for evaluations of earthquake hazards in the Central and Eastern United States, in Seventeenth water reactor safety information meeting, Weiss, A.J., ed.,: Proceedings of the U.S. Nuclear Regulatory Commission NUREG/CP-0105, v. 2, p. 341-365.

Kenner, S.J., and Segall, Paul, 2000, A mechanical model for intraplate earthquakes - Application to the New Madrid Seismic Zone: Science, v. 289, p. 2,329-2,332.

Kumar, Prakash, Kind, Rainer, Yuan, Xiaohui, and Mechie, James, 2012, USArray receiver function images of the lithosphere-asthenosphere boundary: Seismological Research Letters, v. 83, p. 486-491, doi:10.1785/gssrl.83.3.486.

Langbein, John, and Johnson, Hadley, 1997, Correlated errors in geodetic time series-Implications for time-dependent deformation: Journal of Geophysical Research, v. 102, p. 591-603.

Li, Qingsong, Liu, Mian, and Sandvol, Eric, 2005, Stress evolution following the 1811-1812 large earthquakes in the New Madrid Seismic Zone: Geophysical Research Letters, v. 32, doi:10.1029/2004GL022133.

Liu, Lanbo, Zoback, M.D., and Segall, Paul, 1992, Rapid intraplate strain accumulation in the New Madrid Seismic Zone: Science, v. 257, p. 1,666-1,669.

Liu, Mian, Stein, S.A., and Wang, Hui, 2011, 2000 years of migrating earthquakes in North ChinaHow earthquakes in midcontinents differ from those at plate boundaries: Lithosphere, v. 3, p. 128 132.

Mao, Ailin, Harrison, C.G., and Dixon, T.H., 1999, Noise in GPS coordinate time series: Journal of Geophysical Research, v. 104, p. 2,797-2,816.

Mattioli, G.S., and Jansma, P.E., 2007, Evaluation of monument stability and noise associated with campaign and continuous GPS geodesy in the New Madrid Seismic Zone and other areas of unconsolidated sediment: U.S. Geological Survey Final Technical Report, v. 2, p. 19, HQGR0107.

McKenna, Jason, Stein, S.A., and Stein, C.A., 2007, Is the New Madrid Seismic Zone hotter and weaker than its surroundings?, in Continental intraplate earthquakes, Stein, S., and Mazzotti, S., eds.,:

Boulder, Colo., Geological Society of America Special Paper 425, p. 167-175.

Meigs, Andrew, 2013, Active tectonics and the lidar revolution: Lithosphere, v. 5, no. 2, p. 226-229, doi:10.1130/RF.L004.1.

Munson, P.J., Obermeier, S.F., Munson, C.A., and Hajic, E.R., 1997, Liquefaction evidence for Holocene and latest Pleistocene seismicity in the southern halves of Indiana and Illinois-A preliminary overview: Seismological Research Letters, v. 68, p. 521-536.

Newman, Andrew, Stein, S.A., Weber, John, Engeln, Joseph, Mao, Ailin, and Dixon, Timothy, 1999 , Slow deformation and lower seismic hazard at the New Madrid Seismic Zone: Science, v. 284, p. 622. Obermeier, S.F., Bleuer, N.K., Munson, C.A., Munson, P.J., Martin, W.S., McWilliams, K.M., Tabaczynski, D.A., Odum, J.K., Rubin, E.M., and Eggert, D.L., 1991, Evidence of strong earthquake 
shaking in the lower Wabash Valley from prehistoric liquefaction features: Science, v. 251, p. 1,061-1,063.

Odum, J.K., Stephenson, W.J., and Williams, R.A., 2010, Multisource, high-resolution seismicreflection imaging of Meeman-Shelby fault and a possible tectonic model for a Joiner Ridge-Manila High stepover structure in the upper Mississippi Embayment region: Seismological Research Letters, v. 81, p. 647-663.

Page, Morgan, and Hough, Susan, 2014, The New Madrid Seismic Zone-Not dead yet: Science, v. 343, p. 762-764.

Pazzaglia, Frank, Zeitler, P.K., Idleman, B.D., McKeon, R., Berti, Claudio, Enkelmann, E., Laucks, J., Ault, A., Elasmar, M., and Becker, T., 2010, Tectonics and topography of the Cenozoic Appalachians, in Tectonics of the Susquehanna Piedmont, Wise, D., and Fleeger, G., eds.: Lancaster, Penn., Field Conference of Pennsylvania Geologists, Guidebook for the Annual Field Conference of Pennsylvania Geologists, v. 75, p. 111-126.

Peltier, W.R., and Drummond, Rosemarie, 2008, Rheological stratification of the lithosphere-A direct inference based upon the geodetically observed pattern of the glacial isostatic adjustment of the North American continent: Geophysical Research Letters, v. 35, doi:10.1029/2008GL034586.

Petersen, Mark D., Moschetti, Morgan P., Powers, Peter M., Mueller, Charles S., Haller, Kathleen M., Frankel, Arthur D., Zeng, Yuehua, Rezaeian, Sanaz, Harmsen, Stephen C., Boyd, Oliver S., Field, Ned, Chen, Rui, Rukstales, Kenneth S., Luco, Nico, Wheeler, Russell L., Williams, Robert A., Olsen, Anna H., 2014, Documentation for the 2014 update of the United States national seismic hazard maps: U.S. Geological Survey Open-File Report 2014-1091, 243 p., http://pubs.usgs.gov/of/2014/1091/.

Pollitz, F.F., Kellogg, Louise, and Bürgmann, R., 2001, Sinking mafic body in a reactivated lower crust-A mechanism for stress concentration at the New Madrid Seismic Zone: Bulletin of the Seismological Society of America, v. 91, p. 1,882-1,897.

Pollitz, F.F., and Mooney, W.D., 2013, Seismic structure of the Central US crust and shallow upper mantle-Uniqueness of the Reelfoot Rift: Earth and Planetary Science Letters, doi:10.1016/j.eps1.2013.05.042

Salisbury, J.B., Rockwell, T.K., Middleton, T.J., and Hudnut, K.W., 2012, LiDAR and field observations of slip distribution for the most recent surface ruptures along the central San Jacinto Fault: Bulletin of the Seismological Society of America, v. 102, no. 2, p. 598-619, doi:10.1785/0120110068.

Savage, J.C., 1983, Strain accumulation in western United States: Annual Review of Earth and Planetary Sciences, v. 11, p. 11-43.

Schmidt, D.A., and Bürgmann, Roland, 2006, InSAR constraints on the source parameters of the 2001 Bhuj earthquake: Geophysical Research Letters, v. 33, no. 2, doi:10.1029/2005GL025109.

Segall, Paul, and Davis, J.L., 1997, GPS applications for geodynamics and earthquake studies: Annual Review of Earth and Planetary Sciences, v. 25, p. 301-336.

Sella, Giovanni, Stein, S.A., Dixon, Timothy, Craymer, Michael, James, T.S., Mazzotti, Stephane, and Dokka, R.K., 2007, Observations of glacial isostatic adjustment in stable North America with GPS: Geophysical Research Letters, v. 34, doi:10.1029/2006GL027081.

Snieder, Roel, Hubbard, Susan, Haney, Matthew, Bawden, Gerald, Hatchell, Paul, Revil, Andre, and DOE Geophysical Monitoring Working Group, 2007, Advanced noninvasive geophysical monitoring techniques: Annual Review of Earth and Planetary Sciences, v. 35, p. 653-683.

doi:10.1146/annurev.earth.35.092006.145050 
Stein, S.A., 2007, New Madrid GPS-Much ado about nothing?: EOS Transactions American Geophysical Union, v. 88, no.5, p. 59.

Stein, S.A., 2010, Disaster deferred-How new science is changing our view of earthquake hazards in the Midwest: New York, Columbia University Press, 275 p.

Stein, S.A., and Liu, Mian, 2009, Long aftershock sequences within continents and implications for earthquake hazard assessment: Nature, v. 462, p. 87-89.

Stein, S.A., Liu, Mian, Calais, Eric, and Li, Qingsong, 2009, Midcontinent earthquakes as a complex system: Seismological Research Letters, v. 80, p. 551-553.

Tuttle, M.P., Schweig, E.S., Sims, J.D., Lafferty, R.H., Wolf, L.W., and Haynes, M.L., 2002, The earthquake potential of the New Madrid Seismic Zone: Bulletin of the Seismological Society of America, v. 92, p. 2,080-2,089.

Tuttle, M. P., Al-Shukri, Haydar, and Mahdi, Hanan, 2006, Very large earthquakes centered southwest of the New Madrid Seismic Zone 5,000-7,000 years ago: Seismological Research Letters, v. 77, p. 755-770.

Van Arsdale, Roy, and Cupples, William, 2013, Late Pliocene and Quaternary deformation of the Reelfoot Rift: Geosphere, v. 9, p. 1,819-1,831.

Weber, John, Stein, S.A., and Engeln, Joseph, 1998, Estimation of strain accumulation in the New Madrid Seismic Zone from GPS geodesy: Tectonics, v. 17, p. 250-266.

Working Group on California Earthquake Probabilities (WGCEP), 2011, The Uniform California Earthquake Rupture Forecast, version 3 (UCERF3) project plan: Working Group on California Earthquake Probabilities, accessed July, 28 2014, at http://www.wgcep.org.

Zhang, Qie, Sandvol, E., and Liu, Mian, 2009, Lithospheric velocity structure of the New Madrid Seismic Zone: A joint teleseismic and local P tomographic study: Geophysical Research Letters, v. 36, doi:10.1029/2009GL037687.

Zoback, M.L., Zoback, M.D., Adams, J., Assumpcao, M., Bell, S., Bergman, E.A., Blumling, P., Brereton, N.R., Denham, D., Ding, J., Fuchs, K., Gay, N., Gregersen, S., Gupta, H.K., Gvishiani, A., Jacob, K., Klein, R., Knoll, P., Magee, M., Mercier, J. L., Muller, B.C., Paquin, C., Rajendran, K., Stephansson, O., Suarez, G., Suter, M., Udias, A., Xu, Z.H., Zhizhin, M., 1989, Global patterns of tectonic stress: Nature, v. 341, p. 291-298. 


\section{Appendix 1: List of Workshop Participants}

\begin{tabular}{|c|c|c|}
\hline \multicolumn{2}{|c|}{ Participant Name } & \multirow{2}{*}{$\begin{array}{r}\text { Institution } \\
\text { U.S. Geological Survey—Reston }\end{array}$} \\
\hline Michael & Blanpied & \\
\hline Oliver & Boyd & U.S. Geological Survey_Memphis \\
\hline Eric & Calais & Purdue University \\
\hline Ksenia & Dmitrieva & Stanford University \\
\hline Michael & Hamburger & Indiana University \\
\hline Bill & Hammond & University of Nevada \\
\hline Eric & Hetland & University of Michigan \\
\hline *William & Holt & Stony Brook University \\
\hline Susan & Hough & U.S. Geological Survey—Pasadena \\
\hline Nancy & King & U.S. Geological Survey—Pasadena \\
\hline John & Langbein & U.S. Geological Survey—Menlo Park \\
\hline Mian & Liu & University of Missouri-Columbia \\
\hline Harold & Magistrale & FM Global \\
\hline Steve & Marshak & University of Illinois - Urbana-Champaign \\
\hline *Stephane & Mazzotti & University of Montpelier \\
\hline Jill & McCarthy & U.S. Geological Survey—Golden \\
\hline Chuck & Meertens & UNAVCO Consortium \\
\hline Miguel & Merino & Northwestern University \\
\hline Walter & Mooney & U.S. Geological Survey—Menlo Park \\
\hline Fred & Pollitz & U.S. Geological Survey-Menlo Park \\
\hline John & Puchakayala & University of Memphis \\
\hline Paul & Segall & Stanford University \\
\hline *Giovanni & Sella & $\begin{array}{l}\text { National Oceanic and Atmospheric Administration- } \\
\text { National Geodetic Survey }\end{array}$ \\
\hline Bob & Smalley & University of Memphis \\
\hline Seth & Stein & Northwestern University \\
\hline Roy & Van Arsdale & University of Memphis \\
\hline Rob & Williams & U.S. Geological Survey_Golden \\
\hline Yuehua & Zeng & U.S. Geological Survey—Golden \\
\hline
\end{tabular}

*Unable to participate due to weather-related travel interruption. 


\title{
Appendix 2: Workshop Agenda
}

\author{
Advancing Geodesy in the U.S. Midcontinent \\ October 31 - November 1, 2012 \\ Northwestern University, Evanston, Illinois
}

\section{Workshop Agenda}

\section{October 30}

Afternoon/Evening: Participants arrive, check in at Orrington

$\begin{array}{lll}\text { 8:30-10:00 PM } & \begin{array}{l}\text { Informal Icebreaker } \\ \text { Cash bar at Globe Café }\end{array} & \begin{array}{l}\text { Globe Café Den, } \\ \text { Orrington Hotel }\end{array}\end{array}$

\section{October 31}

$7: 30-8: 30$ AM

8:30 AM

$8: 30-8: 45$ AM

$8: 45-9: 15$

$8: 45-9: 30$

\section{Continental Breakfast}

Meeting registration

Workshop begins

Introduction: Meeting organization and goals

- Welcome from organizing committee, USGS

- Review meeting agenda and logistics

- Large-scale goals of workshop
Norris Center, Room 202

Northwestern Room

Norris Center Room 202

Northwestern Room

Organizational Context

- USGS goals for geodetic research and infrastructure (Blanpied/King)

- Role of NSF in Midcontinent Geodesy Research (Chuck Estabrook)

- Review of Boston workshop findings (Boyd)

\section{Session 1: Structural and Neotectonic Context}

- What do we know about midcontinent geological evolution and structure that is relevant to current deformation in the midcontinent?

- How does our knowledge about paleoearthquakes in the New Madrid and broader region inform models of crustal deformation?

\section{Introduction: Rob Williams}

Steve Marshak - Basement Topography of the Midcontinent, USA: A Visual Signature of Fault-Related and Epeirogenic Crustal Displacement

Walter Mooney: Continental Intra-Plate Earthquakes: Correlation with Lithospheric Structure.

Roy Van Arsdale: Structure and Paleoseismology of the New Madrid Seismic Zone 
$9: 30-10: 15$

$10: 15-10: 30$

$10: 30-11: 15$

$11: 15-12: 00$

$12: 00-1: 30$

$1: 30-2: 15$
Fred Pollitz: Mantle Origin for Stress Concentration at the New Madrid Seismic Zone?

Michael Hamburger: Could the next New Madrid earthquake be in the Wabash Valley Seismic Zone?

\section{Break}

Session 2: Models for Intraplate Seismogenesis

- What drives midcontinent deformation and earthquakes? What do mechanical models tell us about intraplate deformation and earthquakes in the New Madrid and broader region? What additional constraints are needed?

\section{Introduction: Paul Segall}

${ }^{1}$ William Holt: Intraplate stress and strain in the North American plate inferred from global dynamic models.

Susan Hough: Moment accrual versus moment release: the NMSZ and Beyond.

Stephane Mazzotti: Can we constrain maximum strain rates and seismicity rates in midcontinent US from rheology models?

Eric Hetland: Reloading of non-plate boundary faults: the potential role of stress reservoirs.

Oliver Boyd: Relaxation and creep in the New Madrid Seismic Zone.

\section{Discussion - Leaders: Main Liu, Paul Segall}

Lunch

Norris Center Room 202

Northwestern Room

\section{Session 3: Geodetic infrastructure and observations}

- What do we know about spatial and temporal patterns of deformation in the midcontinent? What is needed to make progress?

\section{Introduction: Eric Calais}

Chuck Meertens: EarthScope Geodesy in the midcontinent and eastern U.S.

${ }^{1}$ Giovanni Sella: CORS Network and its contribution to assessing the stability of the North American Plate.

Bob Smalley: Examining deformation of plate interiors with GPS: Application to the Central US.

Bill Hammond: Using GPS Geodesy to Assess Very Low Strain Rates in the North American Mid-Continent.

Ksenia Dmitrieva: Network Noise Estimator (NENE) for time-dependent noise in GPS velocities in Intraplate regions.

\footnotetext{
${ }^{1}$ Giovanni Sella and Bill Holt were unable to attend the meeting due to weather-related delays (Hurricane Sandy). These presentations were not given but are retained in the agenda to show that they were considered in the workshop planning.
} 
$2: 15-3: 00$

$3: 00-3: 15$

$3: 15-3: 45$

$3: 45-4: 30$

$4: 30-5: 00$

$6: 30-8: 00$

\section{November 1}

$7: 30-8 \cdot 30 \mathrm{AM}$

$8: 30-8: 45$ AM

$8: 45$ - 10:00 AM

10:00 -10:15

$10: 15-11: 15$

$11: 15-12: 00$

$12: 00-1: 00$

$1: 00-2: 30$
John Langbein: Improving geodetic infrastructure to test models of deformation in the New Madrid Seismic Zone

\section{Discussion - Leaders: Nancy King, Eric Calais}

Break

\section{Session 4: Geodetic Applications to Hazard Estimation}

- How does current data on deformation in the New Madrid and broader region inform earthquake hazard assessment and what additional information is needed to improve that assessment?

Introduction: Michael Blanpied

Yuehua Zeng: Western US GPS observation and application to the national seismic hazard mapping project.

Main Liu: Roaming earthquakes with long aftershock sequences in China highlight earthquake hazard in mid-continents.

Seth Stein: Using GPS to improve New Madrid hazard mitigation and tectonic investigations.

Discussion - Leaders: Harold Magistrate, Michael Blanpied

Summary Discussion

Dinner

Dave's Italian Kitchen

\section{Continental Breakfast}

Morning Logistics

Organization of breakout session

Breakout sessions

- Geodetic targets: location and density

- Infrastructure recommendations: Continuous/campaign GPS

- Analysis/Modeling

- Hazard Assessment applications

Break

Report from breakout groups/discussion

Closing discussion/recommendations

Box lunch; participants depart

Organizing committee drafts outline for report
Norris Center Room 202

Northwestern Room

Room 103 Chicago Room

Room 207 Rock Room 